AT - TADBIR

JURNAL ILMIAH MANAJEMEN

Homepage: ojs.uniska.ac.id/attadbir

\title{
Pengaruh Kepercayaan (Trust) Dan Kualitas Pelayanan Online (E-Service Quality) Terhadap Keputusan Pembelian Online Shop Bukalapak
}

\author{
Ima Nurmanah, Edi Suswardji Nugroho \\ Universitas Singaperbangsa Karawang \\ J1. HS.Ronggo Waluyo, Puseurjaya, Karawang \\ e-mail: 1610631020186@student.unsika.ac.id
}

\begin{abstract}
This research was conducted with the aim of knowing how much influence Trust and E-Service Quality have on purchasing decisions at Bukalapak's online shop. This research uses descriptive verification method with a quantitative approach. The analysis used in this research is scale range analysis, path analysis. The test was conducted to test the validity, reliability test, $t$-test, f-test. Processed with the help of SPSS. Based on the results of the study, it was explained that Trust and online service quality (e-service quality) had a partial and simultaneous effect on purchasing decisions.
\end{abstract}

Keywords: E-commerce, Trust, E-Service Quality, Purchasing Decisions.

\begin{abstract}
Abstrak
Penelitian ini dilakukan dengan tujuan untuk mengetahui seberapa besar pengaruh Trust dan EService Quality terhadap keputusan pembelian pada online shop Bukalapak. Penelitian ini menggunakan metode deskriptif verifikatif dengan pendekatan kuantitatif. Analisis yang digunaka dalam penelitian ini adalah analisis rentang skala, analisis jalur. Pengujian dilakukan uji validitas, uji reliabilitas, t-test, f-test. Diolah dengan bantuan SPSS. Berdasarkan hasil penelitian menjelaskan bahwa Kepercayaan (Trust) dan kualitas pelayanan online (e-service quality) berpengaruh secara parsial dan secara simultan terhadap keputusan pembelian.
\end{abstract}

Kata Kunci : E-Commerce, Kepercayaan, Kualitas Pelayanan Oline, Keputusan Pembelian 


\section{PENDAHULUAN}

Dalam menghadapi Revolusi Industri di bidang ekonomi, pemerintah Indonesia sudah memliki visi besar yaitu pemerintah berharap Indonesia mampu melahirkan bisnis-bisnis digital. Hal ini didukung dengan perkembangan terknologi digital yang bisa merubah perilaku konsumen dengan memilih belanja secara online, karena adanya teknologi digital ini memudahkan para pelaku usaha dalam menawarkan produk atau jasanya. Belanja online merupakan segala aktifitas bisnis yang dalam pelaksanaannya atau setiap kegiatan transaksinya menggunakan sarana aplikasi teknologi informasi dan komunikasi. Dalam melakukan kegiatan transaksi secara online pastinya banyak pertimbangan sebelum melakukan keputusan pembelian. Perilaku konsumen dalam berbelanja online tentu berbeda-beda, ada yang sangat memperhatikan kualitas produk, harga ataupun pelayanan baik dari ecommerce itu sendiri atau penyedia jasa logistik.

Indonesia menjadi negara tercepat dalam pertumbuhan e-commerce di dunia, eksistensi e-commerce di Indonesia pun semakin meningkat dikarenakan infrastuktur internetnya mendukung dan memudahkan dalam mengakses e-commerce atau online shopping. Pertumbuhan ini juga terasa pada tingkat perolehan posisi top brand award dalam kategori online shopping yang fluktuatif. Pada kuartal sebelumya atau 2019 akhir, Bukalapak masih berada diposisi keempat dengan perolehan index $12,7 \%$, namun pada kuartal pertama di 2020 Bukalapak berada diposisi kelima dengan index 5,3\%. Jumlah pengunjung web Bukalapak pun masih kalah dengan ecommerce lainnya, dimana pada setiap kuartalnya selama tahun 2019 terus mengalami penurunan jumlah pengunjung, sampai akhirnya di kuartal 4 pengunjung
Bukalapak hanya berkisar 39.263.300.

Menurut (Philip Kotler, Kertajaya, \& Setiawan, 2019) menjelaskan bahwa konsep kepercayaan pelanggan sudah bersifat horizontal tidak lagi vertikal. Dengan kemudahan konektifitas ponsel memungkinkan pelanggan mengakses saran dan masukkan dari banyak orang sebagai pertimbangan dalam membuat keputusan pembelian. Dalam lingkungan seperti ini, pelanggan lebih banyak menyesuaikan diri dengan opini sosial. Sebelumnya, komunikasi pemasaran hanya dikendalikan oleh perusahaan, namun sekarang perusahaan tidak bisa mengendalikan percakapan yang terjadi antara konsumen yang berkomunikasi satu sama lain. Oleh karena itu perusahaan dan merk yang mempunyai reputasi yang kuat dan klaim jujur tentang produk mereka tidak perlu ada yang dikhawatirkan.

Berdasarkan dari hasil survey yang telah dilakukan oleh ecommerceiq.com mengenai pengalaman pengguna e-commerce dalam beberapa kategori, menjelaskan bahwa pada kategori reputasi perusahaaan, Bukalapak berada pada urutan keempat dan masih dibawah reputasi Blibli, Tokopedia dan Lazada. Serta dalam kategori authentic product, Bukalapak memperoleh 3,9\% dan menjadi urutan terakhir dari keenam ecommerce tersebut, ini menujukan bahwa authentic product yang dimiliki Bukalapak masih terbilang buruk dibanding kelima ecommerce lainnya. Menurut jurnal (Ihsan \& Ade Perdana Siregar, 2019) memaparkan bahwa kepercayaan dapat menggambarkan keadaan perasaan, perilaku, keyakinan dan persepsi. Ada beberapa faktor yang dapat menumbuhkan kepercayaan konsumen yaitu reputasi, kemanan bertransaksi, dan keandalan sistem, serta terjaminnya mutu produk. 


\begin{tabular}{|c|c|c|c|c|c|c|}
\hline & 嘼blibli ${ }^{\text {com }}$ & Bukalapak & JD.ID & LAZADA & StShopee & tokopedia \\
\hline Good reputation & $14.8 \%$ & $13.0 \%$ & $12.9 \%$ & $13.7 \%$ & $10.9 \%$ & $14.3 \%$ \\
\hline Cheaper product price & $6.5 \%$ & $15.1 \%$ & $11.0 \%$ & $13.5 \%$ & $18.0 \%$ & $13.3 \%$ \\
\hline More product selection & $6.5 \%$ & $14.6 \%$ & $5.2 \%$ & $11.3 \%$ & $13.0 \%$ & $16.8 \%$ \\
\hline Authentic products & $13.9 \%$ & $3.9 \%$ & $19.5 \%$ & $7.2 \%$ & $4.2 \%$ & $4.3 \%$ \\
\hline Good customer service & $12.0 \%$ & $8.9 \%$ & $5.2 \%$ & $6.5 \%$ & $7.7 \%$ & $8.8 \%$ \\
\hline Fast delivery & $7.4 \%$ & $6.0 \%$ & $8.6 \%$ & $10.0 \%$ & $7.6 \%$ & $5.8 \%$ \\
\hline Free delivery & $13.0 \%$ & $6.8 \%$ & $14.8 \%$ & $10.6 \%$ & $18.4 \%$ & $3.2 \%$ \\
\hline Easy return policy & $6.5 \%$ & $5.7 \%$ & $2.9 \%$ & $5.4 \%$ & $4.5 \%$ & $5.3 \%$ \\
\hline Easy navigation on site & $4.6 \%$ & $7.0 \%$ & $3.3 \%$ & $3.8 \%$ & $3.5 \%$ & $9.3 \%$ \\
\hline More payment options & $9.3 \%$ & $8.9 \%$ & $11.0 \%$ & $13.4 \%$ & $5.3 \%$ & $8.4 \%$ \\
\hline Better mobile app & $4.6 \%$ & $9.6 \%$ & $5.7 \%$ & $4.4 \%$ & $6.8 \%$ & $9.4 \%$ \\
\hline Loyalty program & $0.0 \%$ & $0.3 \%$ & $0.0 \%$ & $0.0 \%$ & $0.1 \%$ & $0.0 \%$ \\
\hline More promo & $0.9 \%$ & $0.0 \%$ & $0.0 \%$ & $0.0 \%$ & $0.2 \%$ & $0.9 \%$ \\
\hline More secure & $0.0 \%$ & $0.3 \%$ & $0.0 \%$ & $0.1 \%$ & $0.0 \%$ & $0.2 \%$ \\
\hline
\end{tabular}

Gambar 1. Hasil Survey Pengalaman Pengguna E-commerce Sumber: ecommerceiq.com, 2020

Berdasarkan Gambar1. juga menjelaskan bahwa dalam beberapa kategori Bukalapak memperoleh presentase yang masih rendah, misalnya dalam kategori fast delivey, easy return policy, easy navigation site. Permasalahan yang sering dikeluhkan dalam pelayanan oleh konsumen yaitu dalam pengiriman barangnya yang terbilang lambat atau tidak sesuai waktu. Ada beberapa ciri yang mampu menggambarkan suatu pelayanan bisa dikatakan sebagai pelayanan yang baik selain pelayanan secara prima juga harus memberikan kenyamanan kepada pelanggan saat melakukan pelayanan (Kasmir, 2017). Salah satu faktor dalam mempengaruhi pembelian yaitu kenyamanan berbelanja pada situs belanja online. Ketika pelayanannya baik maka pembeli akan merasa nyaman untuk bertransaksi. Dengan kualitas pelayanan yang baik maka akan mempengaruhi konsumen untuk melakukan pembelian.

Adapun rumusan masalah dalam penelitian ini yaitu untuk mengetahui apakah kepercayaan dan kualitas pelayanan online berpengaruh secara parsial maupun simultan terhadap keputusan pembelian pada Bukalapak.

\section{KAJIAN PUSTAKA}

Manajemen Pemasaran

Menurut (Dharmmesta \& Handoko, 2018) menjelaskan bahwa manajemen pemasaran merupakan suatu proses manajemen, yang meliputi penganalisisaan, perencanaan, pelaksanaan dan pengawasan kegiatan pemasaran yang dilakukan oleh perusahaan. Sedangkan, menurut (Assauri, 2017) menyatakan bahwa Manajemen Pemasaran merupakan kegiatan penganalisisan, perencanaan, pelaksanaan, dan pengendalian program-program yang dibuat untuk membentuk, membangun, dan memelihara, keuntungan dari pertukaran melalui sasaran pasar guna mencapai tujuan organisasi (perusahaan) dalam jangka panjang. Berdasarkan pengertian tersebut dapat dikatakan bahwa manajemen pemasaran itu merupakan proses kegiatan dari setiap fungsi-fungsi manajemen dalam menciptakan, membangun, serta mempertahankan kegiatan pertukaran yang menguntungkan melalui pasar sasaran untuk mencapai target/tujuan perusahaan. 


\section{Bauran Pemasaran}

Menurut (Alma, 2016) bauran pemasaran adalah kegiatan mengkombinasikan berbagai kegiatan marketing agar terkombinasi dan hasil yang paling memuaskan ada 4 elemen yang tercakup. Sedangkan untuk bauran pemasaran saat ini terdiri dari elemen 7P, yaitu:

1) Produk, merupakan titik sentral yang terpenting dari kegiatan marketing. Semua kegiatan marketing lainnya digunakan untuk menunjang dari pesmasaran produk.

2) Price, masalah kebijakan penetuan harga akan menentukan keberhasilan pemasaran dari produk. Kebijaksanaan dalam pennetuan harga dapat dilakukan pada setiap tingkatan lembaga yaitu kebijaksanaan harga oleh produsen, grosir dan retailer.

3) Place (Saluran Distribusi), Sebelum produsen memasarkan produknya, maka sudah ada perencanaan tetang pola distribusi yang akan dilakukan. Perantara sangat penting karena mereka yang berhubungan langsung dengan konsumen.

4) Promotion (Promosi), dalam kegiatan pemasaran harus ada keseimbangan dengan produk baik, sesuai dengan selera konsumen, dan dibarengi dengan teknik promosi yang tepat maka akan sangat membantu suksesnya usaha marketing.

5) People, merupakan unsur orang/manusia yang melayani terutama dalam perusahaan yang menjual jasa.

6) Pshysical Evidence, artinya bukti fisik yoang dimiliki perusahaan jasa atau fasilitas yang disediakan.

7) Process, yaitu menggambarkan bagaimana proses yang dilakukan sampai permintaan jasa yang diterima oleh konsumen memuaskan.

Jadi, bauran pemasaran merupakan gabungan atau kombinasi dari semua variabel-variabel pemasaran yang dijalankan dan dikendalikan untuk menghasilkan strategi perusahaan dalam wujud memenuhi kebutuhan konsumen di pasar sasaran.

\section{Kepercayaan (Trust)}

Menurut (Chiou \& Droge,2006) menyatakan bahwa Kepercayaan mencerminkan efek kumulatif dari waktu ke waktu pada loyalitas pelanggan dalam keterlibatan tinggi, produk dari layanan pasar tinggi. sedangkan menurut Garbarino and Lee (2003) menjelaskan bahwa kepercayaan di tempat pemasaran layanan lebih menekankan pada sikap individu yang mengacu pada kepercayaan konsumen dalam kualitas dan keandalan layanan yang diterimanya (Pasharibu, Paramita, \& Febrianto, 2018). Berdasarkan pengertian tersebut dapat dikatakan bahwa kepercayaan adalah keadaan dimana konsumen memiliki rasa keyakinan terhadap individu lain atau suatu bisnis sehingga tidak ada keraguan lagi dalam melakukan kegiatan transaksi. Menurut Mayer et al., (1995) yang dikutip dari penelitian (Ismayanti, Suardana, \& Negara, 2015) terdapat faktor-faktor yang dapat membangun kepercayaan konsumen, sebagai berikut:

1. Kemampuan (ability). Kemampuan mengacu pada kompetensi dan karakteristik penjual atau organisasi dalam mempengaruhi wilayah yang spesifik.

2. Kebaikan hati / perbuatan amal (benevolence). Kebaikan hati merupakan kemauan penjual dalam memberikan kepuasan yang saling menguntungkan antara dirinya dengan konsumen.

3. Integritas (integrity). Integritas berkaitan dengan bagaimana perilaku atau kebiasaan penjual dalam menjalankan bisnisnya. Informasi yang diberikan pada konsumen benar atau tidak. 


\section{Kualitas Pelayanan Online (E-Service}

Quality)

Menurut Rowley (2006) (Ihsan \& Ade Perdana Siregar, 2019) menyatakan bahwa layanan elektronik diartikan sebagai perbuatan, usaha atau pertunjukan yang pengirimannya di mediasi oleh teknologi informasi. Sedangkan menurut Chase, Jacobs, \& Aquilano (2013) (Ulum \& Muchtar, 2018) menjelaskan bahwa Eservice quality adalah sebuah bentuk kualitas layanan yang lebih luas dengan media internet yang menghubungkan antara penjual dan pembeli untuk memenuhi kegiatan berbelanja secara efektif dan efisien. Jadi dapat dikatakan bahwa e-service quality adalah seberapa mampu perusahaan memberikan pelayanan yang lebih luas yang berbasis elektronik dengan mediasi teknologi informasi dan komunikasi.

Berdasarkan Ho dan Lee (2007) yang dikutip dari penelitian (Saputra, Sumpena, \& Akbar, 2018) terdapat 5 dimensi pengukuran e-service quality, yaitu:

1. Information Quality, merupakan kualitas informasi yang tersedia pada website merupakan komponen utama dari kualitas pelayanan yang dirasakan.

2. Security (keamanan) Berkaitan dengan bagaimana kemampuan sebuah website terbukti dapat dipercaya bagi pelanggannya.

3. Website Functionality, berkenaan dengan seberapa jauh kemapuan sebuah website berfungsi.

4. Customer Relationship. Komunitas virtual yang dianggap sebagai organisasi sosial yang terbentuk secara online sebagai sarana komunikasi antara costumer satu dengan yang lainnya dalam bertukar informasi.

5. Responsiveness dan Fulfillment. Dimensi ini berhubungan dengan ketepatan waktu dalam merespons costumer baik itu perihal pertanyaan mengenai produk ataupun respon untuk menjawab komplain customer. Dimensi fulfillment (pemenuhan) lebih mengacu pada keberhasilan dalam memberikan infomasi dan menyampaikan produk atau jasa yang ditawarkan dan kemampuannya dalam mengoreksi kesalahan yang kemungkinan yang akan terjadi selama proses transaksi.

\section{Perilaku Konsumen}

Menurut (Supranto \& Limakrisna, 2017) Perilaku konsumen merupakan tindakan yang langsung terlibat dalam mendapatkan, menggunakan (memakai, mengkonsumsi) dan menghabiskan produk (barang dan jasa) termasuk proses yang mendahului dan mengikuti tindakan ini. Dikutip menurut pendapat Shiffman dan Kanuk (1994) dalam buku (Damiati, et al., 2017) istilah perilaku konsumen merujuk kepada perilaku yang diperlihatkan oleh konsumen dalam mencari, membeli, menggunakan, mengevaluasi, dan menghabislan produk barang dan produk jasa yang mereka harapkan akan memuaskan kebutuhan mereka. Dapat dikatakan bahwa perilaku konsumen adalah sikap atau tindakan seseorang yang terlibat dalam mencari informasi, mendapatkan, membeli, mengonsumsi, menghabiskan, mengevaluasi jasa atau produk yang sudah mereka perkirakan atau harapkan akan mampu memenuhi serta memuaskan kebutuhan mereka.

\section{Keputusan Pembelian}

Menurut (Kotler \& Keller, 2016) mengatakan bahwa keputusan pembelian yaitu beberapa tahapan yang dilakukan oleh konsumen sebelum melakukan keputusan pembelian suatu produk. Sedangkan Menurut (Tjiptono, 2015) keputusan pembelian merupakan sebuah proses yang dimana konsumen mengenal masalahnya, lalu 
mencari informasi mengenai produk atau merek tertentu dan mengevaluasi seberapa baik dari masing-masing alternatif tersebut dapat memecahkan masalahnya, yang kemudian mengarah kepada keputusan pembelian. Jadi kesimpulannya bahwa keputusan pembelian adalah suatu proses yang pengambilan keputusan yang sangat penting dimana konsumen melakukan pencarian informasi mengenai produk atau jasa yang harus diperhatikan konsumen dalam melakukan pembelian.

Pada saat melakukan pembelian ada beberapa faktor yang harus selalu diperhatikan konsumen sebagai bahan pertimbangan. Menurut (Kotler \& Keller, 2016) terdapat enam dimensi keputusan pembelian, diantaranya : Pilihan produk, Pilihan merek, Pilihan penyalur, Jumlah pembelian, Waktu pembelian, dan Metode pembayaran.

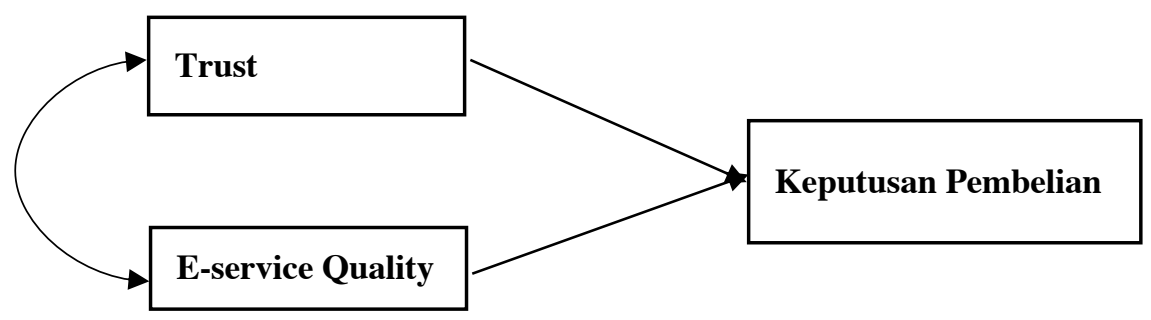

Gambar 2. Kerangka Penelitian Sumber : Kajian Penelitian, 2020

\section{METODE PENELITIAN}

\section{Jenis Penelitian}

Jenis penelitian ini yaitu penelitian kuantitatif. Pendekatan dalam penelitian ini adalah pendekatan Deskriptif dan Verifikatif yang bertujuan untuk menjelaskan bagaimana hubungan dan pengaruh suatu variabel terhadap variabel lainnya. Dimana lokasi penelitiannya pada online shop Bukalapak.

\section{Populasi dan sampel}

Menurut (Suharyadi \& Porwanto, 2016) populasi adalah sebuah kumpulan dari semua kemungkinan orang-orang, benda-benda, dan ukuran yang lain dari objek yang menjadi perhatian. Dalam penelitian populasinya merupakan pegguna Bukalapak, dengan jumlah populasi tidak terhingga. Sedangkan Sampel adalah adalah bagian dari jumlah dan karakteristik yang dimiliki oleh populasi tersebut. Sampel yang diambil dari populasi harus betul-betul representative (mewakili). (Sugiyono, 2017)

Sehingga penentuan ukuran sampel dari populasi ini menggunakan teori menurut Hairs dalam (Ferdinand, 2014) yang menyatakan bahwa pengambilan sampel dilakukan dengan menghitung jumlah indikator dikali lima. Untuk jumlah indikator dalam penelitan ini terdapat 33 indikator. Jadi penetuan jumlah sampel dalam penelitian ini 33 dikali lima yang menghasilkan 165 sampel.

\section{Teknik Pengumpulan Sampel}

Teknik pengumpulan sampel yang digunakan dalam penelitian ini menggunakan Nonprobablity Sampling. Menurut (Sugiyono, 2017) Nonprobality sampling adalah teknik dalam pengambilan jumlah sampel yang tidak memberikan peluang/kesempatan yang sama bagi setiap unsur atau anggota populasi untuk dipilih menjadi sampel. Teknik yang dipakai yaitu 
Purposive sampling dimana teknik penetuan sampel dengan mempertimbangkan hal tertentu. Pertimbangannya yaitu yang pernah melakukan pembelian di Bukalapak minimal satu kali.

\section{Analisis Data}

Teknik analisis data dalam penelitian ini menggunakan analisis rentang skala, analisis jalur. Serta pengujian dilakukan melalui uji validitas, uji reliabilitas, uji normalitas, t-test, f-test.

\section{HASIL DAN PEMBAHASAN}

Hasil

Hasil penelitian uji validitas untuk menguji masing-masing instrumen yang ada pada kuesioner atau menguji ketepatan antara data yang sesungguhnya dengan data yang dapat dikumpulkan oleh peneliti. Dalam penetuan apakah item pertanyaan memenuhi syarat sehingga layak atau tidak layak untuk digunakan. Syarat yang harus dipenuhi harus memenuhi kriteria sebagai berikut:

a) Jika $r \geq 0,30$ maka item - item pernyataan dari kuesioner adalah valid,

b) Jika $r \leq 0,30$ maka item - item pernyataan dari kuesioner dianggap tidak valid.

Dari hasil analisis uji validitas pada tabel 2 diperoleh jumlah pernyataan sebanyak 33 pernyataan, yang secara keseluruhan mendapatkan nilai $r \geq 0,30$, sehingga dapat dikatakan seluruh pernyataan dinyatakan valid.

Pengujian reliabilitas pada tabel 1 dilakukan dengan tujuan untuk mengetahui seberapa jauh hasil pengukuran dua kali atau lebih terhadap gejala yang sama dengan menggunakan alat pengukur yang sama, akan menghasilkan data yang sama. Untuk melihat reliabilitas masing-masing instrumen yang digunakan, menggunakan nilai koefesien cronbach alpha $>0,6$ sebagai syarat dinyatakan reliabel.

Tabel 1. Hasil Pengujian Reliabilitas

\begin{tabular}{|c|l|c|c|c|}
\hline No & \multicolumn{1}{|c|}{ Variabel } & r hitung & r tabel & Kriteria \\
\hline 1 & Kepercayaan (Trust) & 0,862 & 0,600 & Reliabel \\
\hline 2 & $\begin{array}{l}\text { Kualitas Pelayanan Online } \\
\text { (E-Service Quality) }\end{array}$ & 0,889 & 0,600 & Reliabel \\
\hline 3 & Keputusan Pembelian & 0,924 & 0,600 & Reliabel \\
\hline
\end{tabular}

Sumber: Data diolah, 2020

Tabel 2. Hasil Uji Normalitas

\begin{tabular}{|l|c|c|c|}
\hline \multirow{2}{*}{ Variabel } & \multicolumn{2}{|c|}{$\begin{array}{c}\text { Kolmogorov- } \\
\text { Smirnov }\end{array}$} & \multirow{2}{*}{ Kriteria } \\
\cline { 2 - 3 } & r hitung & r kritis & \\
\hline Kepercayaan (Trust) & 0,567 & 0,05 & Distribusi Normal \\
\hline $\begin{array}{l}\text { Kualitas Pelayanan Online } \\
\text { (E-Service Quality) }\end{array}$ & 0,467 & 0,05 & Distribusi Normal \\
\hline Keputusan Pembelian & 0,425 & 0,05 & Distribusi Normal \\
\hline
\end{tabular}

Sumber: Data diolah, 2020 
Tabel 3. Hasil Analisis data

\begin{tabular}{|l|r|r|r|}
\hline \multicolumn{1}{|c|}{ Variabel } & $\begin{array}{c}\text { Koefisien } \\
\text { Jalur }\end{array}$ & thitung & \multicolumn{1}{c|}{ Sig } \\
\hline Trust (X1) & 0,208 & 2,595 & 0,010 \\
\hline E-Service Quality (X2) & 0,610 & 7,618 & 0,000 \\
\hline $\mathrm{R}^{2}$ (Koefisien Determinasi) $=0,616$ & & \\
$\mathrm{R}$ (koefisien Korelasi) $=0,794$ & & \\
F hitung $=130,022$ & & \\
SignifF $=0,000$ & & \\
F tabel $=3,05$ & & \\
t tabel $=1,654$ & & \\
\hline
\end{tabular}

Sumber: Data diolah, 2020

Tabel 4. Hasil Analisis Jalur

\begin{tabular}{|c|c|c|c|c|c|}
\hline Variabel & $\begin{array}{c}\text { Koefisien } \\
\text { Jalur }\end{array}$ & \multirow{2}{*}{$\begin{array}{c}\text { Pengaruh } \\
\text { Langsung }\end{array}$} & \multicolumn{2}{|c|}{$\begin{array}{c}\text { Pengaruh Tidak } \\
\text { Langsung }\end{array}$} & $\begin{array}{c}\text { Subtotal } \\
\text { Pengaruh }\end{array}$ \\
\cline { 4 - 5 } & & X1 & X2 & \\
\hline Trust & 0,208 & 0,043 & - & 0,100 & 0,144 \\
\hline $\begin{array}{c}\text { E-Service } \\
\text { Quality }\end{array}$ & 0,610 & 0,372 & 0,100 & - & 0,472 \\
\hline \multicolumn{7}{|c|}{ Pengaruh Total (Simultan) } \\
\hline
\end{tabular}

Sumber: Data diolah, 2020

Selanjutnya uji normalitas untuk mengetahui persebaran data apakah berdistribusi normal atau tidak. Dasar pengambilan keputusannya dilihat pada grafik distribusi normal serta dengan melakukan pengujian Kolmogorof, dengan ketentuan:

a) Jika angka signifikansi $<0,05$ maka data tersebut berdistribusi secara normal.

b) Jika angka signifikansi $>0,05$ maka data tersebut tidak berdistribusi normal.

Berdasarkan hasil analisis pada tabel 3, diperoleh hasil koefisien korelasi antara variabel bebas dengan nilai sebesar 0,794, dengan demikian korelasi antara variabel Trust dan E-Service Quality memiliki tingkat hubungan yang kuat karena memiliki nilai yang positif dan berada pada interval 0,60 0,799 dengan kategori kuat (Sugiyono, 2017). Berdasarkan hasil tersebut maka dapat diperoleh persamaan jalur sebagai berikut: $\mathrm{Y}=0,208 \mathrm{X} 1+0,610 \mathrm{X} 2+\varepsilon$. Persamaan tersebut dapat diartikan bahwa adanya hubungan asosiatif antara kepercayaan dengan keputusan pembelian sebesar 0,208, artinya bahwa setiap peningkatan kepercayaan sebesar 1 maka akan meningkatkan keputusan pembelian sebesar 0,208 . Angka 0,610 merupakan nilai koefisien untuk kualitas pelayanan online, yang berarti bahwa setiap peningkatan kualitas pelayanan online sebesar 1 maka akan meningatkan keputusan pembelian sebesar 0,610.

Koefisien determinasi (R2) sebesar 0,616 yang berarti $61,6 \%$ variabel keputusan pembelian (Y) dapat dijelaskan oleh variabel Kepercayaan (X1) dan Kualitas Pelayanan Online (X2). Adapun pengaruh dari variabel lain sebesar $1-0,616=0,384$ atau $38,4 \%$ merupakan kontribusi variabel lain yang tidak diteliti. Uji $\mathrm{t}$ (Parsial) menunjukan bahwa variabel kepercayaan (X1) memilki nilai sig $(0,010)<\alpha(0,05)$ dan thitung $(2,595)>$ ttabel $(1,654)$ yang artinya $\mathrm{H} 0$ 
ditolak. Uji t (parsial) untuk variabel (X2) menunjukan bahwa nilai sig $(0,000)<\alpha$ $(0,05)$ dan thitung $(7,618)>$ ttabel $(1,654)$ yang artinya H0 ditolak. Dengan demikian dapat dikatakan bahwa kepercayaan (X1) dan Kualitas Pelayanan Online (X2) berpengaruh secara parsial terhadap Keputusan Pembelian.

Selanjutnya untuk uji $F \quad$ (simultan) menunjukan bahwa nilai sig $(0,000)<\alpha$ $(0,05)$ dan fhitung $(130.022)>$ ttabel $(3,05)$ yang artinya $\mathrm{H} 0$ ditolak. Yang berarti dapat dikatakan bahwa terdapat pengaruh secara simultan atau secara bersama-sama Kepercayaan (Trust) (X1) dan Kualitas Pelayanan Online (E-service Quality) (X2) terhadap Keputusan Pembelian (Y).

\section{Pembahasan}

\section{Pengaruh Kepercayaan Terhadap}

\section{Keputusan Pembelian}

Untuk hasil pengaruh kepercayaan (Trust) terhadap keputusan pembelian yang memilki nilai koefisien jalur 0,208. Lalu untuk pengaruh langsung kepercayaan terhadap keputusan pembelian sebesar 4,3\% serta pengaruh tidak langsungnya sebesar $10 \%$. Sehingga pengaruh parsialnya sebesar 14,4\%. Dengan demikian kepercayaan berpengaruh signifikan terhadap keputusan pembelian. Sehingga dapat dikatakan bahwa kepercayaan akan meningkatkan 14,4 \% keputusan pembelian pada Bukalapak.

\section{Pengaruh Kualitas Pelayanan Online (E-}

Service Quality) terhadap Keputusan

\section{Pembelian.}

Hasil penelitian menunjukan bahwa pengaruh kualiatas pelayanan online memilki nilai koefisien jalur 0,610 atau sebesar $61 \%$. Lalu untuk pengaruh langsung kualitas pelayanan online terhadap keputusan pembelian sebesar $37,2 \%$ dan pengaruh tidak langsungnya $10 \%$. Sehingga pengaruh parsialnya sebesar $47,2 \%$. Dengan demikian
Kualitas pelayanan online berpengaruh signifikan terhadap keputusan pembelian. Sehingga dapat dikatakan bahwa Kualitas pelayanan online akan meningkatkan 14,4\% keputusan pembelian pada Bukalapak.

Berdasarkan hasil penelitian diketahui bahwa pengaruh E-Service Quality lebih besar daripada Trust terhadap keputusan pembelian Bukalapak, hal ini dikarenakan eservice quality ini menjadi penentu keberhasilan selama proses transaksi di dalam situs Bukalapak. Dikarenakan faktor e-service quality ini menjadi tolak ukur keberhasilan Bukalapak dalam memberikan pelayanan elektronik kepada pengguna Bukalapak.

\section{KESIMPULAN DAN SARAN}

\section{Kesimpulan}

Berdasarkan hasil dan pembahasan dalam penelitian dapat ditarik kesimpulan bahwa kepercayaan (trust) mempengaruhi keputusan pembelian pada Bukalapak, yang artinya semakin tinggi atau baik kepercayaan konsumen terhadap Bukalapak maka akan meningkatkan keputusan pembelian di Bukalapak. Begitupun dengan kualitas pelayanan online (e-service quality) berpengaruh positif dan signifikan terhadap keputusan pembelian di Bukalapak, artinya bahwa semakin baik kualitas pelayanan online yang diberikan Bukalapak kepada konsumen maka akan menarik konsumen untuk melakukan keputusan pembelian. Hasil penelitian juga menujukan nilai korelasi antara kepercayaan (trust) dan kualitas pelayanan online (e-service quality) yang menjelaskan bahwa adanya hubungan yang kuat antar variabel tersebut.

\section{Saran}

Hasil penelitian ini diharapkan bisa menjadi bahan evaluasi dan pertimbangan dalam upaya meningkatkan keputusan pembelian di Bukalapak melalui upaya peningkatan 
kepercayaan dan kualitas pelayanan online seperti memberikan kompensasi gratis ongkos pengiriman pada permasalahan keterlambatan pengiriman barang, memberikan informasi ketersediaan barang yang jelas dan akurat, memberikan respon yang cepat dalam menangani keluhan konsumen dengan cara Bukalapak menyediakan layanan keluhan konsumen diberbagai media yang dapat langsung dihubungi oleh konsumen. media yang disediakan bisa difungsikan dengan baik dalam menangani keluhan konsumen. Dalam hal penyampaian informasi juga harus bisa dipahami oleh konsumen sehingga meminimalisir pertanyaan atau keluhan berulang sehingga konsumen merasa keluhannya teratasi dengan baik.

Penelitian ini masih banyak keterbatasan dan kendala diantaranya sulitnya mendapatkan responden dengan cepat, masih banyak variabel lain yang mempengaruhi keputusan pembelian diluar dari variabel yang diteliti. Maka dari itu untuk peneliti selanjutnya disarankan juga untuk menambahkan variabel lain seperti, price, e-security seals, perceived risk dan lain-lain, serta bisa menggunakan alat analisis diluar SPSS.

\section{DAFTAR PUSTAKA}

Alma, B. (2016). Kewirausahaan. Bandung: Alfabeta.

Assauri, S. (2017). Manajemen Pemasaran Dasar, Konsep \& Strategi. Jakarta: PT RajaGrafindo Persada.

Damiati, Masdarini, L., Suriani, M., Adnyawati, N. M., Marsiti, C. R., Widiartini, K., et al. (2017). Perilaku Konsumen. Depok: PT.RajaGrifindo Persada.

Dharmmesta, B. S., \& Handoko, T. (2018). MANAJEMEN PEMASARAN Analisis Perilaku Konsumen. Yogyakarta: BPFEYogyakarta.

Ferdinand, A. (2014). Metode Penelitian Manajemen Pedoman Penelitian Untuk
Penulisan Skripsi, Tesis, dan Disertasi Ilmu Manajemen. Semarang : Badan Penerbit Unviersitas Diponegoro.

Ihsan, M., \& Ade Perdana Siregar. (2019).

Pengaruh E-service Quality Terhadap

Keputusan Pengguna Jasa Ojek Online Go-Ride dalam Aplikasi Go-Jek melalui Kepercayaan Konsumen. J-MAS (Jurnal Manajemen dan Sains), 6.

Ismayanti, N. N., Suardana, I. M., \& Negara, K. I. (2015). Pengaruh Kepercayaan dan E-Service Quality Terhadap Keputusan Pembalian Pada Akomodasi di Bali Pada Situs Booking.com. Jurnal IPTA, 6.

Kasmir. (2017). Costumer Service Excellent Teori dan Praktik. Jakarta: Raja Grafindo. Kotler, P., \& Keller, K. L. (2016). Marketing Management 15th Global Edition. England: Pearson Education Limited.

Pasharibu, Y., Paramita, E. L., \& Febrianto, S. (2018). Price, service quality and trust on online transportation towards customer satisfaction. Jurnal Ekonomi dan Bisnis, 25.

Philip Kotler, Kertajaya, H., \& Setiawan, I. (2019). Markwting 4.0 Bergerak Dari Tradisional Ke Digital. Jakarta: Gramedia Pustaka Utama.

Saputra, D. M., Sumpena, S., \& Akbar, Y. (2018). Analisis Pengaruh E-Service Quality Terhadap Customer Satisfaction Yang Berdampak Pada Customer Loyallty PT.Bayu Buana Travel TBK. CKI On SPOT, 8.

Sugiyono. (2017). Metode Penelitian Kuantitatif, Kualitatif, dan R\&D. Bandung: Alfabeta.

Suharyadi, \& Porwanto. (2016). Statistika Untuk Ekonomi dan Keuangan Modernisasi. Jakarta: Salemba Empat. Supranto, J., \& Limakrisna, N. (2017). Perilaku Konsumen dan Strategi Pemasaran untuk Memenangkan Persaingan Bisnis. Jakarta: Mitra Wacan Media. 
Tjiptono, F. (2015). Strategi Pemasaran Edisi 4. Yogyakarta: CV. ANDI.

Ulum, F., \& Muchtar, R. (2018). PENGARUH E-SERVICE QUALITY TERHADAP E-CUSTOMER SATISFACTION WEBSITE STARTUP KAOSYAY. Jurnal Tekno Kompak, 5. 